PAEDAGOGIA ChRISTIANA

I/21 (2008) - ISSN 1505-6872

Danuta Wajsprych*

Olsztyn

\title{
Wychowanie integralne jako emancypacyjna przestrzeń edukacji religijnej
}

Poniekąd normą współczesnej, pluralistycznej kultury globalnej stała się szybka, powszechna i nieprzewidywalna zmienność w każdej dziedzinie, pociągając za sobą przewartościowanie wszystkich niemal usankcjonowanych tradycją wartości. U wielu ludzi spragnionych (być może złudnie) ,jednej, jedynej, prawdziwej drogi" sytuacja ta rodzi poczucie niepewności. Zachodzące zmiany postrzegają oni wyłącznie w kategoriach zagrożenia, a nie szansy rozwoju. Znamienna wszak stała się specjalizacja i wszechogarniająca konkurencja.

W epoce przemian nie jest łatwo zdecydować się na stabilne myślenie i działanie, ale jednocześnie należy dostrzegać konieczność nieustannego poddawania ich rewizji oraz tworzenia od nowa. Jeżeli pluralizm zdobył obywatelstwo w kulturze i nauce, to nie sposób w jakiejś mierze nie otworzyć się na niego również i w Kościele ${ }^{1}$. Rozpoczęty proces pogłębiania się specjalizacji ukształtował takie mechanizmy, że nie ma obecnie siły, by go zatrzymać. Wartości, konkurując ze sobą, zajmują takie miejsce i wytwarzają tak swoisty układ, że godzi on w cały system wartości.

Wspomniane zjawiska i procesy nie mogą wszakże być normami dla rozwoju pedagogiki religii i kształtowania się jej statusu. Decydujące zdanie w tym względzie powinien mieć nadal autorytet Kościoła i badania naukowe teologii. Niemniej jednak nie należy w swojej refleksji zamykać się na inne nauki humanistyczne, a zwłaszcza pedagogikę i psychologię, co więcej, musimy być świadomi ich decydującej roli w integralnym rozwoju człowieka. Podobnie Kościół, urzeczywistniając się w świecie, powinien poważnie liczyć się z przemianami w nim zachodzącymi, a pedagogika religii wsłuchana w głos Kościoła, przy równo-

* Dr Danuta Wajsprych, prodziekan Wydziału Pedagogicznego Olsztyńskiej Szkoły Wyższej im. J. Rusieckiego.

${ }^{1}$ M. Majewski, Metodologia katechetyki w teorii i w praktyce, Kraków 1998, s. 42. 
czesnym otwarciu się na przemiany, będzie z pewnością dynamiczniejsza i dojrzalsza ${ }^{2}$.

Niniejszy artykuł koncentruje się wokół powstania i uprawomocnienia koncepcji integralnego nauczania i wychowania, koniecznej, jak się wydaje, do stworzenia całościowej (pełnej) wizji rozwoju współczesnego człowieka. Podstawą do zaprezentowania pedagogii integralnego rozwoju człowieka będą poglądy pedagogiczno-religijne ks. M. Majewskiego, jednego z wybitniejszych pedagogów religii i katechetyków ostatniego stulecia ${ }^{3}$.

Dziś już nikogo nie dziwi, że wielu naukowców poszukuje nowego paradygmatu cywilizacji, aby przenieść go na grunt edukacyjny. Poszukiwania te kieruje się ku czemuś otwartemu, większemu i szerszemu, noszącemu znamiona pewnej uniwersalności. Jest to tęsknota za mądrością życia, która byłaby solidnie potwierdzona przez naukę i pozostawałaby w służbie zjednoczonego, braterskiego świata. Zwłaszcza, że gdzieś w samej głębi człowieka istnieje marzenie o pełnej jedności. Marzenie to jest szczególnie pociagające w epoce rozczłonkowania, niekończących się rozróżnień i rozpadu.

Można sądzić, że tę rolę porządkującą i wytyczającą twórcze myślenie o człowieku i otaczającym go świecie spełnia wciąż na nowo pedagogia integralna, rozumiana jako całościowy obszar rozważań nad edukacją w świetle uniwersalnych wartości wypracowanych $\mathrm{w}$ toku cywilizacji dziejów ${ }^{4}$. Pedagogia integralna nabiera szczególnego znaczenia dziś, gdy znaleźliśmy się w sferze wolności bez odpowiedzialności z wpływami różnorodnych opcji edukacyjnych i miejscem eksperymentowania „ziemią” niczyją. Dzieje się to w kraju, gdzie wiele sponsorowanych ruchów wywołuje chaos, uderza w fundamentalne wartości, używa demagogicznych haseł, utrudniając wyciaganie wniosków oraz niszcząc zdrowy rozsądek. Tak zwana „wiedza gorąca” pokazuje jednocześnie, że w Europie mamy z jednej strony wciąż duchowy bolszewizm, z drugiej alternatywę humanistyczną, która niestety uwolniła wielu ludzi z fundamentalnych wartości osobowych ${ }^{5}$. Jest to bez wątpienia kryzysowa sytuacja pogranicza, która stanowi wyzwanie do kształtowania nowych moralnie postaw ${ }^{6}$.

2 Tamże, s. 43.

${ }^{3}$ Ks. M. Majewski (1928-1999), prof. katechetyki i pedagogiki religii. Podczas niemal wszystkich lat aktywności zawodowej profesora Majewskiego obowiązywała narracja pedagogiczna, która nie dawała możliwości, ze względu na cenzurę, interpretacji przestrzeni edukacyjnej w duchu chrześcijańskim. Majewski jednak z odwagą stawiał sobie pytania, jak przerwać zastój owej narracji, unikając cofania się, jak wspomagać i stymulować rozwój indywidualny i wspólnotowy, jak przygotowywać się do zmian, które nastąpią? Podjął tym samym walkę z fundamentalistycznym myśleniem w i o pedagogice swoich czasów, wypracowując oryginalną koncepcję integralnego rozwoju człowieka.

${ }^{4}$ S. Michałowski, W stronę pedagogiki integralnej, w: F. Adamski (red.), Poza kryzysem tożsamości. W kierunku pedagogiki personalistycznej, Kraków 1993, s. 147.

${ }^{5}$ Tamże, s. 148.

${ }^{6}$ A. Grzegorczyk, Filozofia czasu próby, Warszawa 1984, s. 233. 
Głównym zatem zadaniem edukacji jest ciagłe poszukiwanie tego, co integralne i uniwersalistyczne, dążenie do pogodzenia ujęć prawdziwościowych zagadnień pedagogicznych, zgromadzonych w dziejach myśli ludzkiej, zmierzanie do uporządkowania systemu wychowania i kształcenia poprzez nauczanie słowem i czynem. Tak pojęta edukacja integralna zdąża w swych intencjach do pedagogiki wieczystej wyrażonej swego czasu przez Jacka Woronieckiego ${ }^{7}$. Oprócz niego w historii polskiej pedagogiki jako przedstawicieli wychowania integralnego wymienia się: Józefa Mirskiego ${ }^{8}$, Ludwikę Jeleńską ${ }^{9}$ oraz przedstawicieli personalizmu, a wśród nich Karola Górskiego ${ }^{10}$, a także licznych pedagogów katolickich ${ }^{11}$. Współczesnymi przedstawicielami pedagogiki integralnej są: S. Kunowski ${ }^{12}$, M. Gogacz ${ }^{13}$ i J. Tarnowski ${ }^{14}$.

Wymienieni wyżej przedstawiciele integralnego ujęcia wychowania bardzo różnie je określają. $\mathrm{Z}$ metodologicznego punktu widzenia jest ono rozumiane jako: „,kierunek postulujący rozpatrywanie zjawisk jako części całości, w szczególności negujący możliwość atomizowania tych fragmentów rzeczywistości, które odnoszą się do organizmów żywych, zjawisk psychicznych i społecznych, różnych form organizacji”"15.

Twórcą takiej formy nauczania i wychowania przez katechezę na terenie Polski jest niewątpliwie M. Majewski. Wszystkie jego publikacje wyrażają potrzebę integralnej jedności wychowania i nauczania religijnego. Systematyczny jej obraz autor zawarł w pracach: Propozycja katechezy integralnej ${ }^{16}$ oraz Tożsamość katechezy integralnej ${ }^{17}$.

Zasadę integracji, na której opiera się ten model edukacji religijnej, tłumaczy językiem literatury psychologicznej. Za S. Szumanem podaje, iż

rozwój psychiczny można rozpatrywać z dwóch punktów widzenia: ilościowego i jakościowego. Przez rozwój ilościowy rozumiemy „rozrastanie się” psychiczne i rozwojowe, zróżnicowanie psychiczne czyli dyferencjację. Równolegle do proce-

${ }^{7}$ J. Woroniecki, Katolicka etyka wychowawcza, Lublin 1986 oraz: Program pedagogiki integralnej O. J. Woronieckiego, w: M. Malinowski (oprac.), Paideia chrześcijańska, cz. 1: Wychowanie człowieka w nauczaniu Kościoła, Warszawa 1991, s. 267.

${ }^{8}$ T. Drynta, Teoretyczno-metodologiczne problemy w twórczości J. Mirskiego, w: B. Żechowsa (red.), Z metodologicznych i empirycznych problemów pedagogiki, Katowice 1990, s. 54-59.

${ }^{9}$ L. Chmaj, Prady i kierunki w pedagogice XX wieku, Warszawa 1963, s. 123.

${ }^{10}$ K. Górski, Wychowanie personalistyczne, Poznań 1936.

${ }^{11}$ K. Michalski, Katolicka idea wychowania, Poznań 1937; K. Mazurkiewicz, Wychowanie w świetle chrześcijańskiej prawdy, Potulice $1937 \mathrm{i}$ in.

${ }^{12}$ S. Kunowski, Podstawy wspótczesnej pedagogiki, Łódź 1981.

${ }^{13}$ M. Gogacz, Osoba zadaniem pedagogiki. Wyktady bydgoskie, Bydgoszcz 1997.

${ }^{14} \mathrm{~J}$. Tarnowski, Problem chrześcijańskiej pedagogiki egzystencjalnej, Warszawa 1982.

${ }^{15}$ A. Podsiad, Z. Więckowski (oprac.), Mały stownik terminów i pojęć filozoficznych, Warszawa 1983, s. 136.

${ }^{16}$ M. Majewski, Propozycja katechezy integralnej, Łódź 1978.

${ }^{17}$ Tenże, Tożsamość katechezy integralnej, Kraków 1995. 
sów dyferencjacji idą zawsze procesy integracji, czyli scałkowania i centralizacji. [...] Poszczególne treści, przeżycia i funkcje psychiki są ze sobą powiązane i w każdej chwili jest czynna mniej lub więcej cała psychika, a nie tylko oddzielna jej cząstka $^{18}$.

I tak M. Majewski, tłumacząc pojęcie integracji, sięga również do teorii dezintegracji pozytywnej K. Dąbrowskiego, który rozróżnia w rozwoju psychicznym człowieka integrację pierwotną i wtórną, opartą na dezintegracji. Zdaniem K. Dąbrowskiego, „w procesie dezintegracji pozytywnej, ewolucyjnej możemy rozróżnić zasadniczo dwie fazy: 1. wstępną fazę niejako biernego, przeważnie nieświadomego, ścierania się niezgodnych lub sprzecznych tendencji oraz 2. fazę, w której widoczny jest czynny udział zespołu elementów dyspozycyjnych, kontrastujących, coraz bardziej świadomych, które osłabiając lub wzmacniając procesy dezintegracji, wprowadzają nowy układ hierarchii czy tendencji w dezintegrowaną strukturę (zaczątki integracji wtórnej) ${ }^{19}$.

Zarysowane powyżej procesy integracji i dezintegracji na pewno przybliżają nam pojęcie ,,integracji”, lecz nie wyjaśniają w pełni integralnej koncepcji nauczania i wychowania religijnego, kształtowanej przez rzeczywistość humanistyczną i teologiczną ${ }^{20}$. Religijna edukacja integralna, jak podaje M. Majewski, jest przedłużeniem, rozwinięciem i pogłębieniem katechezy korelacji, która zespala objawienie Boże i doświadczenie człowieka. Pojęcie korelacji przeniknęło do katechezy z teologii systematycznej. Jak zauważa M. Majewski: „W kierunku korelacji spotykają się ze sobą objawienie Boże i doświadczenie człowieka dla kształtowania we wnętrzu człowieka mocnego ośrodka duchowego, zdolnego do samostanowienia, samoplanowania i samorealizacji dla dobra siebie i innych" 21. Aby objawienie zbawienia było dobrze zrozumiane, potrzebna jest jego obecność w konkretnych życiowych warunkach katechizowanych. I odwrotnie, aby właściwie pojacc i ocenić sytuację egzystencjalną człowieka, należy zawsze odwoływać się do objawienia. Można zatem stwierdzić, iż w katechezie korelacji między objawieniem Bożym a doświadczeniem ludzkim istnieje proces dialogiczny ${ }^{22}$. Jak zauważamy, religijna edukacja integralna znajduje się na linii katechezy korelacji, ale nie można jej wyłącznie do niej sprowadzić ${ }^{23}$.

${ }^{18}$ S. Szuman, Rozwój dzieci i młodzieży, Warszawa 1948, s. 3-4, cyt. za: M. Majewski, Tożsamość..., s. 64.

${ }^{19}$ K. Dąbrowski, Higiena psychiczna, Warszawa 1962, s. 79, 86, cyt. za: M. Majewski, Tożsamość..., s. 65.

${ }^{20}$ M. Majewski, Tożsamość..., s. 66.

${ }^{21}$ Tenże, Katecheza permanentna, Kraków 1989, s. 185; por. J. Michalski, Korelacja jako zasada współczesnego nauczania religii, Paedagogia Christiana 1/13 (2004) s. 121-123.

${ }^{22}$ S. Chrost, Modele katechezy szkolnej, w: M. Majewski (red.), Aktualne wyzwania katechetyczne, Kraków 1997, s. 81-82.

${ }^{23}$ M. Majewski, Katecheza wierna Bogu i człowiekowi, Kraków 1986, s. 66; J. Michalski, Korelacja..., s. 127. 
Model integralnej edukacji religijnej - jak podaje jej twórca - rozwija zasady teologiczne (wierności Bogu i człowiekowi), psychologiczne (dyferencjacji i integracji), pedagogiczne (interakcji i komunikacji) oraz dydaktyczne (koncentracji i korelacji). Jest modelem, który wyrasta z życia Kościoła i świata, zaś punktem wyjścia jego integralności jest różnorodność czasowa, środowiskowa i kulturowa. Koncepcja integralnego nauczania i wychowania, będąc obecna zarówno w świecie, jak i w Kościele, włącza się w rozwój osoby, wspólnoty i wiary. Jest koncepcją otwartą, dialogiczną, dynamiczną i perspektywiczną 24 .

Koncepcja wychowania i nauczania integralnego postuluje zatem przede wszystkim całościowe rozumienie edukacji, które nie może abstrahować od kwestii wychowania estetycznego, moralnego czy religijnego, a człowieka powinna uznać za podmiot edukacji, akcentując tym samym godność osoby ludzkiej ${ }^{25}$. Taka koncepcja całościowego rozwoju człowieka może stać się podstawą edukacyjnego oporu wobec wszechogarniającej młode pokolenie „kultury instant”, a także postmodernistycznego relatywizmu. Żyjąc obecnie w społeczeństwie otwartym, młodzież wyraźnie podlega podstawowym procesom, takim jak sekularyzacja, pluralizm i subiektywizacja. Pomiędzy tymi procesami zachodzi ścisły związek, co oznacza, że są one wzajemnie uwarunkowane.

Rezultaty oddziaływania wymienionych procesów na postawy i zachowania ludzi są wielorakie. Dostrzega się pod tym względem podstawowe przesunięcie socjalizacyjne i inkulturacyjne, tj. utratę wpływu wychowawczego przez rodzinę, szkołę i Kościół na rzecz kultury masowej (mass media, widowiska, reklama, moda) i niekontrolowanych grup rówieśniczych ${ }^{26}$. Społeczeństwo otoczone jest przez hiperprzestrzeń kultury popularnej i masowej: wielokanałowa telewizja, dziesiątki kolorowych magazynów, wideo-kino w domu, bogate oferty rynkowe, imprezy masowe i kameralne, światowa sieć informacji komputerowej, erupcja turystyki i migracji, fundamentalizmów i relatywizmów ${ }^{27}$. Co to oznacza dla kształtowania się tożsamości współczesnego człowieka, zwłaszcza dla młodzieży? W jakiej jest to relacji do tradycyjnych form socjalizacji i inkulturacji? Jak kształtuje wzory podobieństwa i różnice? Odpowiedź na te pytania może być

${ }^{24}$ M. Majewski, Propozycja.., s. 8; tenże, Katecheza wierna..., s. 65.

${ }^{25}$ Podkreśla się, że założenia antropologiczne dotyczące natury ludzkiej w wychowaniu, mają charakter aprioryczny, a więc opierają się na „wierze” w określoną wizję człowieka. Ma to związek z pedagogiką personalistyczną, w której porzuca się statyczną koncepcję „osoby” i poszukuje żywych, zanurzonych w antropologię i egzystencję determinantów życia osobowego. Dotyczy to w równym stopniu pedagogiki religii, jak i np. antypedagogiki. Zob. W. Granat, Personalizm chrześcijański. Teologia osoby ludzkiej, Poznań 1985, s. 74; M. Nowak, Personalizm historyczny $i$,pedagogie” o inspiracji personalistycznej, w: Z. Kwieciński (red.), Alternatywy myślenia o/dla edukacji. Wybór tekstów, Warszawa 2000, s. 211-238.

${ }^{26}$ Z. Kwieciński, Tropy - ślady - próby. Studia i szkice z pedagogii pogranicza, Poznań-Olsztyn 2000, s. 331.

${ }^{27}$ Z. Melosik, Tożsamość, ciało i władza. Teksty kulturowe jako (kon)teksty pedagogiczne, Poznań-Torun 1996, s. 312. 
bardzo ważnym głosem w debacie nad epistemologią i „,rusztowaniem kategorialnym" postmodernizmu ${ }^{28}$. Wymienione wyżej zjawiska nie pozostają też bez wpływu na życie konfesyjne społeczeństwa, a zwłaszcza młodzieży. Zauważa się tu następujące tendencje: spadek praktyk religijnych i poczucia sacrum. Jak wiadomo, Kościół katolicki zawsze dostarczał sensu i orientacji dla życia codziennego. Obecnie obserwuje się wyraźny spadek tej roli Kościoła. Słabe uczestnictwo w praktykach religijnych związane jest z osłabieniem wiary, a także z zanikaniem poczucia sacrum. Z kościelnego punktu widzenia najbardziej niepokojąca jest tendencja do kształtowania się postaw selektywnych wobec religii, związana z procesem indywidualizacji, prywatyzacji i subiektywizacji posłannictwa religijnego. Tendencja ta godzi w Kościół, a nawet w chrześcijaństwo. Zmierza ona bowiem do tzw. religijności prywatnej ${ }^{29}$.

Masowa kultura konsumpcji oraz wyraźne tendencje przesuwania granic socjalizacji ${ }^{30}$ stawiają zarówno przed rodzicami, jak i pedagogami pytanie, w jaki sposób reagować na taką sytuację? Otóż odpowiedź na nie prosta nie jest, bowiem dorośli podlegają tak samo wpływom kultury współczesnej jak i młodzież. Z. Melosik podaje cztery możliwości wyboru: świadome dążenie do zablokowania istniejących trendów kulturowych, w imię uznanych, tradycyjnych wartości kulturowych; bezrefleksyjne dryfowanie wraz z szybko zmieniającą się kulturą; akceptacja euforii supermarketu i bezkrytyczne ,klikanie” w rzeczywistość, tak jak gdyby to była strona z Internetu; negocjacja z młodzieżą kształtu rzeczywistości, w której wspólnie żyjemy, a w szczególności kształtowanie w młodzieży nawyku świadomego podejmowania wyborów odnośnie kształtu „własnego ja"31.

Autor nie poddaje wątpliwości, że możliwy jest tyko wybór ostatniej propozycji. Tylko ona bowiem, jego zdaniem, daje pedagogice możliwość realnego uczestnictwa w kształtowaniu tożsamości, marzeń i życia współczesnej młodzieży ${ }^{32}$. Wydaje się jednak, że istnieje jeszcze jedna odpowiedź, a mianowicie, że bez blokowania istniejących trendów kultury współczesnej możliwe jest dążenie w wychowaniu do wzajemnego przenikania uznanych, tradycyjnych wartości kulturowych.

Pedagogia M. Majewskiego usytuowana w perspektywie egzystencjalnej, antropologicznej, personalistycznej i dialogicznej koncepcji wychowania człowieka wydaje się być taką odpowiedzią. Wychowanie integralne M. Majewskiego akcentuje znaczenie godności ludzkiej, i zwraca uwagę na fakt, że rozwój

28 Tamże, s. 316.

${ }^{29}$ Por. W. Piwowarski, Katolicyzm polski jako religijność narodu, w: W. Zdanowicz (red.), Religia i życie społeczne, Poznań-Warszawa 1983, s. 66-82.

${ }^{30}$ Socjalizację rozumiemy tu szeroko jako spontaniczne wrastanie w normy zachowań społecznych, jak i naturalne przyswajanie norm i wzorów kultury symbolicznej. Zob. Z. Kwieciński, Edukacja wobec nadziei i zagrożeń współczesności, Referat na III Ogólnopolskim Zjeździe Pedagogicznym, Poznań 1998.

${ }^{31}$ Z. Melosik, Wychowanie - w którq stronę?, w: Z. Kwieciński, B. Śliwerski (red.), Pedagogika, t. 2, Warszawa 2003, s. 89.

${ }^{32}$ Tamże, s. 91. 
człowieka prowadzący do pełnej dojrzałości nie polega na negowaniu i emancypacji z tradycji kulturowej, ale na jej ciagłej interpretacji ${ }^{33}$.

Ważność poszukiwań w teorii całościowego rozwoju człowieka widoczna jest głównie tam, gdzie ukazują one zasady konstytuowania i rozwoju podmiotowości oraz tam, gdzie wskazują na kryzysy i impasy towarzyszące temu procesowi. Podstawą namysłu nad tą teorią wydaje się być uwzględnienie racji, iż dekalog przejęty i wchłonięty przez chrześcijaństwo spowodował, że nikt dziś świadomie nie powie „zabijaj”, „kradnij”, „poniewieraj rodzicami”, „kłam”. W tym sensie i w takim znaczeniu wszyscy ludzie zaczynają budować swoja tożsamość i podmiotowość, opierając je na historii Jezusa, na niej też kształtuja swoje życie, poczucie misji, wartości i bezpieczeństwa, niezależnie od tego, jak bardzo są skłonni przyjmować bądź odrzucać instytucje nauczające o dekalogu. Początek każdej pedagogiki jest zatem w „,isagogii”, czyli w tym, co nazywamy studiami nad Pismem Świętym. Czy chcemy, czy też nie, tam właśnie są wartości, które ukształtowały znaczącą część świata i setki pokoleń. Pedagogia integralnego rozwoju człowieka w swoich celach, treściach, zadaniach uprawomocnia antropologiczną wizję człowieka, pozostającego w dialogu z Bogiem i z prawda, której szukać należy w Ewangelii ${ }^{34}$.

Podczas swojej egzystencji człowiek może w jakimś sensie postawić pod znakiem zapytania dotychczasowe pojmowanie samego siebie, a zarazem odkryć nową możliwość życia, także życia chrześcijańskiego w wymiarze historycznym i eschatologicznym. Majewski za pomocą strategii krytycznego myślenia próbował tworzyć w wychowaniu religijnym przestrzenie wyjścia poza dominujące interpretacje i reprezentacje świata. Sugerował możliwość konstruowania alternatywnych systemów znaczeń, w których młodzież, odrzucając fundamentalizm wychowawczy, sama może tworzyć świat, w którym żyje, i wybierać swoją tożsamośćc ${ }^{35}$.

Wpływ na ewolucję i kształt wychowania najpierw antropologicznego, a później integralnego w poglądach M. Majewskiego, miały niewątpliwie publikacje niemieckich pedagogów religii, a mianowicie M. Stallmanna i K. E. Nipkowa. Pierwszy zbudował pedagogiczno-religijny program edukacji rozumiejącej, bazując na koncepcji hermeneutycznej, drugi natomiast opracował program edukacji religijnej rozumiejącej, posiłkując się koncepcją tematyczno-problemową. Konsekwencją tej inspiracji było postawienie diagnozy, iż dzisiejsze czasy cechuje pomniejszenie czy wręcz degradacja znaczenia tradycji, której nośnikiem są przede wszystkim teksty. Tradycja, ujęta jako historyczno- kulturowy dorobek ludzkości, staje się niezrozumiała dla współczesnego człowieka. Jednak to w niej spoczywa klucz do prawdy o egzystencji ludzkiej. Tradycja domaga się więc

${ }_{33}^{3}$ M. Majewski, Katecheza permanentna..., s. 151.

${ }^{34}$ Por. A. Nalaskowski, Po co nam obchody tysiaclecia? Stowo na otwarcie obrad, w: A. Nalaskowski, K. Rubacha (red.), Pedagogika u progu trzeciego tysiaclecia. Materiaty pokonferencyjne, Toruń 2001, s. 10-12.

${ }^{35}$ M. Majewski, Tożsamość ..., s. 161. 
interpretacji, i to interpretacji egzystencjalnej, a nie ,z dystansu”. To właśnie interpretacja tradycji (historii ludzkości oraz wytworów ludzkiego ducha: dzieł sztuki i tekstów), która poprzez swoje egzystencjalne odniesienie ukazuje prawdę o kondycji człowieka, a zarazem o możliwościach jego istnienia, jest jednym z podstawowych zadań szkoły ${ }^{36}$.

Skoro każde nauczanie jest zorientowane na określoną hermeneutykę życia, oznacza to, że edukacja religijna sytuuje się w zakresie zadań pedagogiki i dydaktyki ogólnej. Chrześcijaństwo stanowi bowiem jeden z zasadniczych fundamentów tradycji europejskiej. Podstawowy tekst chrześcijaństwa, jakim jest Biblia, w wysokim stopniu inspirował rozwój kultury duchowej. Edukacja religijna proponuje więc określoną hermeneutykę ludzkiej egzystencji. Omawiając podstawowe zagadnienia religijne, w procesie dydaktycznym analizuje się zarazem kondycję ludzką, ponieważ - jak uważał Majewski - każde pytanie religijne zakłada pytanie o człowieka. Stąd też w sytuacji dzisiejszej szkoły lekcje religii okazują się być jednym z nielicznych przedmiotów, który realizuje podstawowe zadanie edukacji humanistycznej, a mianowicie ukazuje znaczenie wymiaru egzystencjalnego w kształceniu, wprowadza w humanistyczną tradycję, uwrażliwia go na ,głos historii”, a zarazem umożliwia pozyskanie określonego rozumienia, tożsamości i orientacji w świecie.

Majewski w budowaniu swojej teorii integralnego rozwoju człowieka nawiązał do teorii warstwicowej, zapoczątkowanej przez Wilhelma Flitnera (1933), którą następnie pogłębił S. Hessen w pracy O sprzeczności i jedności wychowania (1939). Pierwsze pełne ujęcie teorii warstwicowej przedstawił S. Kunowski w pracy Proces wychowawczy i jego struktury już w 1947 roku $^{37}$.

Majewski podobnie jak Kunowski, przedstawiając przedmiot pedagogiki religijnej jako nauki, stwierdza, że jest nim całościowy proces rozwoju wychowanka ku pełni człowieczeństwa. Zatem teoretyczna refleksja autora nad pedagogiką, ujawnia już integralne podejście do procesu wychowania. Podstawowym centrum omawianej koncepcji jest człowiek, charakteryzujący się ontyczną złożonością ciała i duszy, pierwiastków zmysłowo-zwierzęcych i duchowo-boskich, a więc pełny człowiek. Podobne stanowisko w odniesieniu do wychowania zajmuje J. Maritain, reprezentujący humanizm integralny. Pisze on: „Filozofia wieczysta” wychodzi poza empiryczny opis człowieka, dlatego nie ogranicza się do zaproponowania pragmatycznego jedynie modelu wychowania”. Ważne jest, by odwołać się do natury człowieka, ,jego bytowej struktury, kultury duchowej i jej elementów, sensu życia"38.

Takie ujęcie przedmiotu wychowania wskazuje na występowanie w życiu człowieka kontinuum rozwojowego. Oznacza to przechodzenie przez etapy rozwojowe w ciągu całego życia. Wychowanie więc, w ujęciu teorii warstwicowej,

${ }^{36}$ Por. K. E. Nipkow, Der pädagogische Umgang mit dem weltan-schaulich-religiösen Pluralismus auf dem Prüfstein, Zeitschrift für Pädagogik 42 (1996), z. 1, s. 57-70; M. Stalmann, Evangelischer Religionsunterricht, Düsseldorf 1968, s. 16-29.

${ }^{37}$ S. Kunowski, Podstawy wspótczesnej pedagogiki, Łódź 1981.

${ }^{38}$ S. Kowalczyk, Wprowadzenie do filozofii J. Maritaina, Lublin 1992, s. 47. 
obejmuje całe życie człowieka i z tego punktu widzenia nabiera charakteru integralnego. Proces całożyciowej edukacji obejmuje zatem warstwę biologiczna, psychologiczna, socjologiczna, kulturologiczną i duchowo-światopoglądową. Natomiast czynnikami rozwoju człowieka są: bios, etos, agos i los $^{39}$.

$\mathrm{Na}$ rolę integracji i hierarchizacji wszystkich wartości w procesie wychowania zwraca uwagę m.in. R. Guardini ${ }^{40}$. Podkreśla on, iż istnieją one immanentnie w człowieku, w jego nie tyle stałości, co w dążeniu do doskonałości, do celu nazywanego pełnym szczęściem, przy jednoczesnej świadomości własnej słabości, a także w Bogu. Wydobycie tego faktu umacnia integralną koncepcję wychowania i nauczania, co można zauważyć właśnie na przykładzie modelu integralnej edukacji religijnej.

Wypracowana przez Majewskiego koncepcja wpisuje się w model edukacji religijnej nazywany konfesyjno-dialogicznym - edukacji, która nauczając i wychowując w tradycji konfesyjnej, nie zamyka wychowanków na dialog i współpracę. Jest to jednocześnie taki rodzaj formacji, który jest zorientowany na człowieka i jest w tym bliski antropologicznie ukierunkowanej koncepcji edukacji religijnej. Ujmuje się ją w tym modelu jako edukację rozumiejąca, która ma służyć odnowie ludzkiego życia poprzez kształtowanie nowych sposobów samorozumienia i bytowania w świecie ${ }^{41}$. Model konfesyjno-dialogiczny eliminuje zatem odwieczny dylemat: jedynie informacja czy jedynie świadectwo wiary? Reorientacja humanistyczna pedagogiki religii ostatnich dziesięcioleci, otwierając nauczanie religijne na człowieka, na jego sytuacje, pytania, nie oznacza zerwania z tradycją i nauczaniem Kościoła. Raczej pomaga w odczytaniu źródeł chrześcijańskiej wizji wychowania w sposób, który jest bliższy współczesnemu człowiekowi ${ }^{42}$.

Koncepcja wychowania integralnego człowieka pokazuje też nowe możliwości edukacyjne religii. Mam tu na myśli jej potencjał emancypacyjny i krytyczny. Mianowicie Majewski podkreślał znaczenie socjalizacji jednostki jako istoty społecznej, która nie jest w stanie uwolnić się od mimowolnych wzorców zachowań i myślenia. Dotyczy to również obszaru religii, gdzie wiedza i przekonania religijne uczniów kształtowane są przez wyobrażenia potoczne. Będąc wzorcami asymilowanymi w procesach socjalizacji, wyobrażenia ulegają petryfikacji, w wyniku czego świadomość religijna zostaje zafiksowana na poziomie dziecięcym. Majewski postulował przezwyciężenie myślenia o religii i edukacji

${ }^{39}$ S. Kunowski, dz. cyt., s. 89.

${ }^{40}$ R. Guardini, Bóg daleki - Bóg bliski, Poznań 1991, s. 272. Guardini podkreśla, że świat wartości ewangelicznych jest światem wszystkich znanych nam wartości (integralność), a ich chrześcijański charakter polega na odniesieniu do Boga przez Jezusa Chrystusa (hierarchiczność). Zatem podstawowa funkcja wychowania chrześcijańskiego polega na integracji i hierarchizacji wszystkich wartości znajdujących się w konkretnym ludzkim świecie, w konkretnej ludzkiej i bożej perspektywie.

${ }^{41}$ J. Bagrowicz, Edukacja religijna wspótczesnej młodzieży. Źródta i cele, Toruń 2000, s. 146.

${ }^{42}$ Tamże. 
religijnej jako funkcjonalnej, stabilizującej czy organizującej, na korzyść myślenia o niej jako sile krytycznej, transformującej, dynamicznej i wyzwalającej. W tym sensie edukacja religijna, według Majewskiego, ma charakter emancypacyjny, zakłada bowiem zmianę wyobrażeń religijnych uczniów, a także zmianę ich samych, prowadząc do rozwoju osobowości i pełnej autonomii. Konsekwencją przyjęcia takiej perspektywy poznawczej jest przekonanie, że życie człowieka postrzegane jest w kategoriach szeroko rozumianej zmiany, a nie stanu posiadania. Kategorie opisu świata mają charakter procesualny, wspólnotowy i komunikacyjny, a kultura jest traktowana jako zbiór możliwych i zmieniających się interpretacji rzeczywistości. Interpretacje te nie są zbiorem nakazów, zakazów i stałych reguł, lecz punktami widzenia, które wymagają zrozumienia, uzasadnienia, rewizji i zmiany. Taką wizję świata podtrzymują m.in. poczucie dialogowej struktury sensu, antyfundamentalizm, samorozumienie i krytyczna samoświadomość ${ }^{43}$.

Krytyczny charakter edukacji religijnej wiązałby się natomiast z uwzględnianiem w niej ideologicznego kontekstu ludzkiej egzystencji (władza, panowanie, użycie, przemoc). Majewski podkreślał, iż młodzież, żyjąc w takiej rzeczywistości, umacniana często zachowaniem własnych rodziców, chce sama w takim życiu uczestniczyć uwiedziona jego blichtrem. Stąd edukacja religijna nigdy nie jest za mało krytyczna, wręcz przeciwnie, jej zadaniem jest właśnie uodpornienie młodego człowieka na wpływy różnego rodzaju ideologii, a także zdecydowana rewizja potocznych wyobrażeń ${ }^{44}$.

Jakie są zatem perspektywy rozwojowe pedagogii integralnego rozwoju człowieka u początku trzeciego tysiąclecia? Współczesna pedagogika, choć nie jest już związana z instytucjonalnym funkcjonowaniem, to z pewnością wykazuje duchowe „przylgnięcie” do wyuczonych teorii, co w praktyce oznacza niechęć ludzi, w tym i pedagogów, do permanentnego uczenia się wciąż na nowo i co oznacza także trudno zmieniającą się mentalność człowieka, która właściwie formowana pomogłaby mu w poznaniu całej prawdy o sobie, tzn. kim jest i dokąd zmierza, a także prawdy o świecie i społeczeństwie. W świetle powyższego nasuwa się konieczność zwrócenia się ku propozycji pedagogii integralnej, która jest jednocześnie ,pedagogia perennis", gdyż jej podmiotem pozostaje zawsze człowiek ale w dialogu z Bogiem. Według wizji integralnego rozwoju człowiek jest bytem, który pozostaje w koniecznej relacji do Boga. Edukacja religijna zatem jest nie do oddzielenia od integralnej formacji osoby. Pęknięcie między religią i życiem znajduje się u korzeni chaosu duchowego, który przeżywamy być może właśnie dzisiaj. Ponadto to pęknięcie jest obecne także w wychowaniu, wprowadzając i do niego duchowy chaos ${ }^{45}$.

${ }^{43}$ T. Adorno, Neutralizacja religii. Studia z osobowości autorytarnej, Warszawa 1999, s. 111-115; Por. Z. Kwieciński, Pedagogika emancypacyjna, w: Z. Kwieciński, B. Śliwerski (red.), dz. cyt., s. 212.

${ }^{44}$ M. Majewski, Tożsamośćc..., s. 166.

${ }^{45}$ Por. J. Michalski, Edukacja i religia jako źródła rozwoju egzystencjalno-kognitywnego. Studium hermeneutyczno-krytyczne, Torun 2004, s. 183-218. 
Poznawszy teorię integralnego rozwoju człowieka, przekonujemy się, że nie można lekceważyć w procesie edukacji wychowania religijnego, jeśli chce się zapewnić człowiekowi wewnętrzną wolność, która jest jednym z wymiarów jego bytu i jednym z głównych celów wychowania. Iluzją pozostaje więc wychowanie areligijne pod pretekstem troski o przyszły wolny wybór. Nieokreślenie, ignorancja i próżnia nie zabezpieczają bowiem wolności, lecz ją zabijają ${ }^{46}$. Jednym z warunków ludzkiej wolności jest móc zrezygnować z własnej wiary wówczas, gdy poznało się jej humanizującą rolę w życiu. Jeśli w trakcie naszej egzystencji opowiadamy się przeciwko niej, to jest to akt wolny, ze znajomością przyczyn, jeśli jednak wytrwamy w tej wierze, to jest to też akt wolny i ze znajomościa przyczyn. Można zatem powiedzieć za personalistami ${ }^{47}$, że nie ma nic bardziej wolnego niż akt wiary dojrzałej. Przekonuje nas o tym właśnie pedagogia integralnego rozwoju człowieka.

Pedagogia M. Majewskiego, czerpiąc inspirację z Biblii, prowadzi do ukazania podstaw wychowania, na których opiera się chrześcijański ideał wychowawczy. Szczególnie ważne są tu dane antropologii biblijnej, ukazujące wizję człowieka, który pochodzi od Boga, i choć skażony jest grzechem, to wciąż wspierany jest mocą Chrystusowej łaski, przywracającej mu godność dziecka Bożego. Edukacja ta jest zatem widziana w całości procesu wychowawczego jako jeden z etapów rozwoju życia duchowego człowieka. Prowadzi ona do rozwoju jednostki we wszystkich wymiarach życia, wspomaga naturalny rozwój, pomaga odnaleźć swoje miejsce w życiu społecznym i życiu Kościoła. Jej zadaniem jest więc pomoc w odnalezieniu osobowej i chrześcijańskiej tożsamości.

Nie podlega zatem dyskusji postulat reorientacji kształcenia i wychowania religijnego, które powinny uznać za swój podmiot nie tyle całe społeczeństwo, państwo czy Kościół, ile ucznia, który dzięki takiemu podejściu do edukacji może zdobyć świadomość nowych możliwości bycia, rozwijać się ku dojrzałości, autonomii i wolności. W tym kontekście edukacja religijna powinna odpowiedzieć na dwa zasadnicze pytania. Po pierwsze: jakie zagadnienia dotyczące bezpośrednio wychowanków, nadają się do wykorzystania, aby na ich przykładzie ukazać im znaczenie i wagę wiary chrześcijańskiej dla samorozumienia i orientacji w świecie? Po drugie: jakie zagadnienia, które stanowią o wierze chrześcijańskiej, nadają się do tego, aby na ich przykładzie ukazać wychowankom znaczenie i wagę tejże wiary dla samorozumienia i orientacji w świecie?

Pytania powyższe zainicjowały liczne badania dotyczące elementaryzacji procesu dydaktycznego. W tym względzie Majewski wyprzedził niejako późniejsze postulaty pod kątem edukacji religijnej, by stawała się procesem dynamicznym, dopasowanym pod względem formy i treści do wymogów współczesności. Przecież obecnie twierdzi się, że edukacja humanistyczna, a więc i religijna po-

${ }^{46}$ Por. tenże, Wychowanie religijne ,wychodzqce od czlowieka i zorientowane na czlowieka”, Paedagogia Christiana 1/9 (2002), s. 33-49.

${ }^{47}$ Por. J. Maritain, Dynamika wychowania, Znak 436 (1991), s. 29-36. 
winna odwoływać się do podstawowych doświadczeń człowieka, a mianowicie zagadnień ważnych życiowo, zagadnień elementarnych, czyli podstawowych i prymarnych, a przez to uniwersalnych przeżyć ludzkich, oraz doświadczeń kluczowych - przeżyć w decydujący sposób wpływających na interpretację rzeczywistości.

Majewskiemu chodziło raczej o myślenie całościowe, referencyjne i uczestniczące, pozwalające nam traktować człowieka w relacjach osobowych. Jest to konieczne, aby zbudować współczesny paradygmat edukacji opartej na nowych fundamentach, jakimi są: wizja, wola, odwaga i nadzieja. Podstawowym założeniem tak pojmowanej pedagogii jest rozpatrywanie wszelkich zabiegów i procesów wychowawczych w ścisłym powiązaniu z całokształtem rzeczywistości, uwzględniając aspekty psychologiczne, energetyczne i duchowe. Wynika to z faktu, że człowiek jest wielowymiarowy, że jego działania są podyktowane różnorodnymi motywami, świadome i nieświadome, że ma wbudowane układy poznawcze, emocjonalne i wolicjonalne, że żyje jednocześnie w świecie zewnętrznym i wewnętrznym ${ }^{48}$. Kolejnym faktem jest to, że musimy człowieka akceptować w całości. Nie można przecież zaprzeczyć temu, co racjonalne, ani temu, co irracjonalne, ani intelektowi, ani emocjom, ani nauce, ani religii.

Człowiek jest istotą dynamiczna, przechodzi od jednego bieguna do drugiego, uwalniając się od uwarunkowań na drodze poszukiwania prawdy i całościowej orientacji ku jedności, ku istocie rzeczywistości i jednocześnie szerszemu kręgowi uniwersalnych wartości. Należy tu odwołać się do prac A. N. Whiteheada, Ch. Hartshorna i jego uczniów, w których proponuje się spójne połączenie naukowej i religijnej wizji świata, stworzenia i człowieka. Ruch na rzecz rozwoju możliwości ludzkich zawiera się w przygotowaniu do uwolnienia człowieka od konwencji roli i wyzwolenia jego indywidualności i niepowtarzalności ${ }^{49}$.

Istotą analiz dokonanych w niniejszym artykule było wykazanie, że integralnie ujęta edukacja religijna może zostać włączona do systemu oświaty publicznej, przyczyniając się jednocześnie do realizacji zadań edukacyjnych szkoły i Kościoła. Jak się bowiem wydaje, pomiędzy Kościołem i szkoła, a także pomiędzy religią a pedagogiką, możliwy jest dialog prowadzony w imię obrony podmiotowości człowieka.

Dialog - co należy podkreślić - nie jest czymś z założenia danym, lecz o wiele bardziej zadanym. Dokonuje się on bowiem między bytami autonomicznymi, a zarazem zależnymi od określonego środowiska, czasu, przepływu idei czy też przyjętych paradygmatów. Wychodząc z założenia, że nie występuje jakaś jedna pedagogika, ani też wyłączna droga religijna w świecie, zasadne jest stwierdzenie, że nie dysponujemy również jakimś ostatecznym wykładem istoty, zadań oraz sposobów realizacji wychowania. $\mathrm{W}$ takiej perspektywie poznawczej należy

${ }^{48}$ S. Michałowski, dz. cyt., s. 149.

${ }^{49}$ N. M. Wildiers, Obraz świata a teologia, Warszawa 1985, s. 238; M. Roland, Edukacja elastyczna, Toruń 1991, s. 36. 
też lokować teorię integralnego wychowania człowieka i traktować ją raczej jako jeden z wielu alternatywnych sposobów jego całożyciowego rozwoju.

Warto na koniec wyrazić przekonanie, że zaprezentowana w artykule teoria integralnego rozwoju człowieka nie może poniekąd uniknąć konfliktu interpretacji, tak jak i cała hermeneutycznie wyrażona pedagogia ludzkiej duchowości. Nie wytwarza ona bowiem jednolitego systemu twierdzeń naukowych, lecz generuje twierdzenia raczej konkurencyjne i kontekstualne. Tymczasem edukacja jako działanie kontekstualne, niekierowane świadomością celów ani przekonaniem o rozumieniu natury wychowania, dla wielu pedagogów jest niesatysfakcjonujące. Bardzo trudno bowiem jest zrezygnować z przekonań o wartości tego, co mamy do zaoferowania innym. Ponadto koncepcja integralnego rozwoju człowieka nie zgadza się też na tendencje dążące do empirycznego, biologicznego czy też ekonomicznego zawężenia teorii edukacji, co jest powodem jej ciąłej krytyki. Jednak w mojej opinii pedagogika, która chce się zajmować edukacją w kontekście całości procesów życiowych, skazana jest na taką nieoznaczoność.

\section{The integral education as liberation space of religious education (Summary)}

It is the content of article the conception of the integral education which postulates towards full moon of human nature general process of the pupil's development. The man, is the basic centre of conception the complexity of body and the soul, elements - animal and spiritually - divine, and so the full man. Conception this goes out pose man's empirical description, therefore it does not restrain to proposing the pragmatic only model of education. Important it is, to appeal to the man's nature, his vital structure, spiritual culture and her elements, sense of life. Such formulation of object of education shows on occurrence in man's life developmental continuum, which hugs man's whole life and it with this point of sight gathers integral character. 